\title{
EEFSEC wt Allele
}

National Cancer Institute

\section{Source}

National Cancer Institute. EEFSEC wt Allele. NCI Thesaurus. Code C126627.

Human EEFSEC wild-type allele is located in the vicinity of $3 q 21.3$ and is approximately $273 \mathrm{~kb}$ in length. This allele, which encodes selenocysteine-specific elongation factor protein, is involved in the translation of selenocysteine-containing proteins. 